\title{
O hOMEM (1887), De AluísIo Azevedo, COMO BEST-SELLER ERÓTICO
}

O HOMEM (1887), BY ALUISIO AZEVEDO, AS EROTIC BEST-SELLER

Leonardo Mendes*

ORCID 0000-0002-8318-3759

\section{Cleyciara Garcia Camello* \\ ORCID 0000-0002-6244-653X}

*Universidade do Estado do Rio de Janeiro Rio de Janeiro, RJ, Brasil

\section{Resumo}

Embora fosse respeitado nos círculos intelectuais desde o aparecimento de $O$ mulato (1881), Aluísio Azevedo (1857-1913) só assinou contrato com a Livraria Garnier após a publicaçáo de $O$ homem (1887). Foi graças ao sucesso de vendas desse livro que o editor de Machado de Assis, um dos mais importantes da época, comprou os direitos de toda a ficção do autor e imprimiu a quarta edição da obra. O feito era resultado de uma forte campanha publicitária posta em curso por Aluísio Azevedo e sua rede de amigos da imprensa. Com foco nas vendas, eles apostaram no aspecto licencioso da obra para divulgá-la e alcançaram grande êxito. O Rio de Janeiro se viu escandalizado ao ler os devaneios eróticos da protagonista, descritos para tratar do tema da histeria feminina. Aluísio Azevedo sofreu ataques dos detratores da estética naturalista, que o acusaram de escrever "pornografia" disfarçada de ciência. Neste artigo, vamos contar a história de $O$ homem como best-seller erótico do fim do século XIX.

Palavras-chave: Aluísio Azevedo, naturalismo, O homem, pornografia.

\section{Abstract}

Despite gaining respect in intellectual circles since the appearance of The Mulatto (1881), Aluísio Azevedo (18571913) only signed a contract with Garnier Bookstore after the publication of The Man (1887). It was thanks to the success of this book that Machado de Assis' publishers, one of the most important at the times, bought the copyright of

\section{Résumé}

Bien que respecté dans les milieux intellectuels depuis la parution de $L e$ Mulâtre, roman brésilien (1881), Aluísio Azevedo (1857-1913) ne sera publié par la Librairie Garnier qu'après le lancement de L'Homme (1887). C'est grâce au succès de vente de ce dernier livre que l'éditeur de Machado de Assis, l'un des plus importants de l'époque, a 
the author's whole works of fiction and printed its $4^{\text {th }}$ edition. The feat was the result of a strong advertising campaign put in motion by Aluísio Azevedo and his network of friends in the press. Focusing on sales, they relied on the licentious aspect of the work to publicize it. Rio de Janeiro was shocked to read the protagonist's erotic fantasies, described to address the issue of female hysteria. Aluísio Azevedo was attacked by naturalism detractors, who accused him of writing "pornography" disguised as science. In this article, we'll tell the story of The Man as an erotic best-seller.

Keywords: Aluísio Azevedo, naturalism, $O$ homem, pornography. acquis les droits de publication de toute l'œuvre fictionnelle d'Azevedo et publié la quatrième édition du roman. Le succès de L'Homme fut le résultat d'une forte campagne publicitaire mise en place dans la presse par Aluísio Azevedo et son entourage. Visant surtout les ventes du livre, ils ont parié, avec succès, sur ses éléments licencieux afin de le faire diffuser et y réussissent largement. La ville de Rio de Janeiro a été scandalisée par les rêveries érotiques de la protagoniste, décrites minutieusement sous prétexte d'aborder le sujet de l'hystérie féminine. Aluísio Azevedo subit l'attaque des détracteurs de l'esthétique naturaliste, qui l'accusaient d'avoir écrit de la " pornographie » sous le masque de la science. Dans cet article, nous proposons de raconter l'histoire de L'Homme en tant que best-seller érotique de la fin du XIX siècle.

Mots-clés: Aluísio Azevedo, naturalisme, L'Homme, pornographie.

Dentro do universo de impressos disponíveis nas livrarias brasileiras no final do século XIX, os chamados "livros para homens", considerados impróprios para as mulheres (que os liam escondidos de pais e maridos), representavam o carro-chefe de vendas dos estabelecimentos, ao mesmo tempo que desafiavam os códigos morais e religiosos da época (EL FAR, 2004). $\mathrm{O}$ rótulo servia para descrever o tipo de impresso à venda, classificando-o como "erótico", "obsceno" ou "pornográfico". Esses vocábulos circulavam como sinônimos na imprensa e nos documentos do final do século XIX, significando "escritos imorais" em sentido amplo. As distinçóes que fazemos atualmente entre "pornografia" (representação sexual transparente) e "erotismo" (esteticismo e jogos verbais) (MAINGUENEAU, 2010) não existiam e, portanto, não se aplicam às fontes e à ficção do século XIX. Nos debates e conversas literárias do período, as palavras "pornografia", "erótico", "licencioso" e "obsceno" eram intercambiáveis e serão empregadas alternadamente neste estudo. 
Na categoria de "livros para homens" enquadravam-se antigos romances libertinos, novas e baratíssimas brochuras pornográficas apócrifas, assim como romances naturalistas franceses, portugueses e brasileiros (MENDES, 2016). O termo era aplicável a livros capazes de incitar o leitor a fazer sexo gratuito, só ou acompanhado, mesmo que não tivessem sido produzidos para esse fim (como os romances naturalistas). Ao invés de um modo de representação, a pornografia pode ser pensada como "um modo de ler" (MOULTON, 2000, p. 11). A pornografia refere-se a "uma interação entre leitor e texto, e náo à intenção textual ou autoral" (THAUVETTE, 2012, p. 46). Numa sociedade pobre de representaçóes de sexo e nudez, a ficção naturalista era capaz de despertar a imaginação licenciosa e de fazer o coraçáo bombear sangue. Era uma das escritas mais sexualmente explícitas daquela sociedade.

Em público, os autores naturalistas rejeitavam a percepçáo de que o romance que escreviam era literatura erótica, mas ao mesmo tempo valiam-se desse "mal-entendido" para criar polêmica, atrair compradores e aumentar as vendas (GARCIA CAMELLO, 2018). Para os livreiros e o grande público, o romance naturalista era um impresso obsceno que circulava no contexto da popularizaçáo do livro e da leitura no final do século XIX (EL FAR, 2004), e não um "romance experimental" ou "estudo de caso", como propunham os homens de letras. Quando lançou O homem em 1887, Aluísio Azevedo e seus amigos valeram-se deliberadamente desse "mal-entendido" para transformar o romance num best-seller erótico, ao lado de Volúpias: 14 contos galantes (1886), de Rabelais (pseudônimo do escritor português Alfredo Gallis), e dos romances naturalistas A carne (1888), de Júlio Ribeiro, e O aborto (1893), de Figueiredo Pimentel (MENDES, 2016). Essas obras alcançaram vendas de 5 a 6 mil exemplares em alguns meses, números até então inauditos para livros brasileiros, qualificando-os como best-sellers eróticos do fim do século XIX.

Neste estudo, vamos contar a história da publicação de $O$ homem e de sua divulgação como livro erótico. Nossas fontes são, além da ficção do período, notas, notícias, crônicas, poemas e resenhas publicados nos periódicos das últimas décadas do século XIX e consultadas online na Hemeroteca Digital Brasileira (http://memoria.bn.br). Nosso intuito é contribuir para a renovação dos estudos sobre o naturalismo no Brasil, redimensionando-o e redescrevendo-o a partir do estudo de novas fontes e da formulaçáo de novas perguntas ao corpus. Para a historiografia tradicional, O homem é uma obra fracassada e menor (BOSI, 1972), um "livro falso" (PEREIRA, 1988, p. 149), o mais científico dos romances de Aluísio Azevedo, numa tradição crítica em que ser "científico" é um defeito. Do ponto de vista da história cultural, entretanto, $O$ homem foi um acontecimento social e literário que agitou o país nos anos de 1887 e 1888, desdobrando-se em polêmicas, conferências, jantares e peças teatrais. $\mathrm{O}$ erotismo do livro foi crucial para o seu sucesso. 
Em 10 de outubro de 1887, foi publicada no Rio a primeira edição de $O$ homem, com o selo da Tipografia de Adolfo de Castro e Silva \& Cia. O livro trazia uma polêmica advertência: "Quem não amar a verdade na arte e não tiver a respeito do naturalismo ideias claras e seguras, fará, deixando de ler esse livro, um grande obséquio a quem o escreveu". Reconhecia que havia um mal-entendido em relação ao naturalismo e que este romance em especial - sobre o sexo (ou sua falta) na vida de uma moça branca e bemnascida, a chamada "histeria" - podia ser lido não como um "estudo", mas como literatura erótica. Antes do naturalismo, o sexo só havia aparecido na "literatura burlesca ou obscena, de que é exemplo o poema 'A origem do mênstruo', de Bernardo Guimarães” (CANDIDO, 1991, p. 126). A advertência era um aviso de isenção de responsabilidade que transferia a licenciosidade para o leitor. Que leitor se excluiria? Excluir-se da leitura não só seria tolo - já que o ato de ler costuma ser privado -, como também uma admissão de estupidez. Aluísio Azevedo sabia que a advertência funcionava como um convite de leitura: $O$ homem era literatura naturalista séria ou "livro para homens"?

A personagem central do romance é Magdalena, ou Magdá, descrita no início da história como uma moça alegre. Após o pai lhe revelar ser Fernando, o amor de sua vida, seu meio irmáo, e da morte repentina do rapaz, ela passa a viver sob profunda prostração, progressivamente se desconectando da realidade ao redor. O médico familiar, Dr. Lobão, diagnostica a histeria. Magdá passa então por vários graus do desenvolvimento da doença, culminando na loucura e no assassinato do trabalhador Luís, o amante da moça em suas picantes alucinaçôes. A preocupação do pai aumenta com o passar do tempo e o agravamento da saúde da filha. Do começo ao fim o médico pressiona o pai para casar Magdá, pois só isso resolveria o problema: "Casamento é um modo de dizer, eu faço é questáo do coito! Ela precisa de homem!" (AZEVEDO, 1989, p. 43), esclarece. O médico prescreve o sexo - não o casamento - como curativo da histeria e caminho de restauração da saúde corporal e mental.

Desde Madame Bovary (1857), de Gustave Flaubert, o tema da sexualidade e imaginação reprimidas da mulher - a chamada "histeria" - foi trabalhado e retrabalhado em obras que foram sistematicamente apropriadas como literatura licenciosa. Romances como $O$ homem e $A$ carne colocavam o corpo da mulher no centro de uma narrativa erótica e denunciavam a proibiçáo do sexo para a mulher sem marido. Como escreveu Júlio Ribeiro em $A$ carne, a histeria era sintoma de "uma castidade impossível" (RIBEIRO, 2002 , p. 110). No seu "estudo" sobre o tema, com o título sensacionalista de Mártires da virgindade: romance patológico (1900), Alfredo Gallis defende 
que o sexo era uma "necessidade fisiológica" a que tinham direito todas as mulheres (GALLIS, s/d., p. 13). O romance narra as desventuras de Maria Manuela, moça virgem de 27 anos, que perde o noivo para uma viúva rica. $\mathrm{O}$ romance trata dos padecimentos da moça, que morre sem conhecer o amor. Ao final, o médico faz um discurso contra o "celibato forçado", que só produzia loucas e cadáveres (GALLIS, s/d., p. 159).

Apesar de sua popularidade no século XIX, o personagem da mulher histérica (ou ninfomaníaca) era comum na pornografia desde o século XVII (PEAKMAN, 2003). Ela aparece no romance libertino do século XVIII e em outros best-sellers eróticos do século XIX, como Os seróes do convento, publicado em Lisboa em torno de 1850 pelo pseudônimo M. L., e Volúpias: 14 contos galantes, funcionando como um pretexto para descrever atividade sexual. Essas obras eram populares e conhecidas de Aluísio Azevedo e outros escritores. As histórias das histéricas que aparecem nesses livros se parecem com o infortúnio da heroína de Aluísio Azevedo, "a pobre noiva sem noivo", na descrição de Coelho Neto (Gazeta de Notícias, 16 out. 1887, p. 2). Algumas brochuras pornográficas apócrifas vendidas nas livrarias naquela época, como Memórias de uma mulher insaciável, ou Elvira, a insaciável, tratavam do mesmo tema acalorado de $O$ homem. Para o leitor do período, a protagonista histérica do romance de Aluísio Azevedo prometia uma história quente. $\mathrm{O}$ fim trágico agradava ao gosto popular. A medicalização da sexualidade não turvava o erotismo do livro.

Desde $O$ mulato (1881), Aluísio Azevedo utilizava estratégias de marketing para vender livro (MÉRIAN, 2013). Para divulgar O homem, ele e seus amigos apostaram disfarçadamente no potencial erótico da narrativa. Aluísio contava com vários apoiadores, mas especialmente com o crítico Valentim Magalhães, diretor da revista $A$ Semana e colunista cativo de vários periódicos; o escritor Henrique Coelho Neto, que já era famoso e assinava colunas em vários jornais; e especialmente seu irmão mais velho Artur Azevedo, tão influente quanto Machado de Assis, criador e diretor de periódicos, teatrólogo de sucesso e colunista de prestígio em vários jornais. A eles se juntavam dois importantes jornalistas: Ferreira de Araújo, diretor-proprietário da Gazeta de Notícias, o mais importante jornal da vida cultural do país naquele momento; e José do Patrocínio, diretor do diário abolicionista Cidade do Rio.

Os anúncios sobre $O$ homem começam a surgir no final de 1886 . A primeira referência aparece em dezembro, com o título $A$ filha do Conselheiro (Gryphus, 04 dez. 1886, p. 6). Até junho de 1887, o livro receberia o título que destacava a protagonista. No dia 25 de junho, escrevendo em A Semana, Valentim Magalhães anunciou: "Uma boa notícia: entrou, afinal, para o prelo A filha do Conselheiro, o último romance de Aluísio Azevedo. É de crer que a tenhamos brevemente a conversar conosco, em agradável e íntimo tête à tête" 
(A Semana, 25 jun. 1887, p. 5).Talvez a alteraçáo do título tenha a ver com as expectativas frustradas do romancista quando da publicação de Filomena Borges (1884). A publicidade em torno do nome da heroína promoveu grande expectativa e sucesso de vendas de diversos produtos comerciais, mas o romance foi um fracasso de crítica (LAMONICA, 2015). Possivelmente por essa razão, o autor optou por $O$ homem, um título mais austero que retirava o foco da personagem feminina, sem perder o sentido de carnalidade.

Num esforço sincronizado, Artur Azevedo publica uma coluna de divulgação no mesmo dia 25 de junho de 1887 na Gazeta da Tarde, chamando o romance de Magdá. O título remetia aos perfis femininos das tradiçóes libertina e romântica. Artur revela a estratégia dos apoiadores. Ao mesmo tempo em que revela ser Magdá um "livro ardentíssimo", destaca que era "tão real, tão naturalista quanto Casa de pensáo e o Coruja". "O estudo 'sério' justificava o tratamento de um tema 'proibido"” (SEREZA, 2012, p.185). Sem abrir mão da concepção naturalista do romance como um "estudo de histeria", Artur fornece pistas que associam o livro a vertentes da literatura popular, como o "romance de sensação" e o gótico, sugerindo que "Magdá [era] uma vampira de si mesma". O estado enfermo da moça é atribuído à frustração sexual. O sofrimento gera um "mal que a envenena lentamente" e a obriga a utilizar o sonho como refúgio. Explicando que "o real do histérico é o sonho", Artur revela que nas alucinaçôes a moça vaga "pelos braços de um amante louro", e "a vida rebenta em explosóes inconcebíveis de todos os lados, de todos os pontos" (Gazeta de Tarde, 25 jun. 1887, p. 2).

À medida que a data do lançamento se aproxima, surgem inúmeros reclames nos periódicos da Corte. Em 27 de setembro de 1887, no Jornal do Commercio, lê-se: "Já está no prelo o romance $O$ homem, do Sr. Aluísio Azevedo" (p. 4), incorporando o título definitivo da obra. Dois dias depois, o Novidades comunica o aparecimento iminente do romance: "Brevemente aparecerá à luz da publicidade o novo romance de Aluísio Azevedo - O homem. Tudo pressagia que esta produção do autor da Casa de pensáo e do Coruja obterá o mais lisonjeiro êxito" (Novidades, 29 set. 1887, p. 1). Confiante no seu sucesso, o jornal oferece aos leitores o trecho de um dos sonhos de Magdá como aperitivo. Na semana anterior ao lançamento, como fizera na época de O mulato no Maranhão, Aluísio e apoiadores saíram em panfletagem pelas ruas do Rio de Janeiro. O corpo a corpo levava o artista em pessoa para apresentar o livro como um produto que rompia com o decoro literário. A campanha ajudou para que no dia do lançamento fossem vendidos 300 exemplares, um feito inédito até então (MÉRIAN, 2013).

Na véspera do lançamento, Coelho Neto entrou em campo e proferiu uma conferência sobre o romance no Teatro Príncipe Real. O evento vinha sendo anunciado nos jornais desde o final de setembro. As conferências 
literárias eram acontecimentos concorridos e serviam de vitrine para os autores promover a si mesmos e aos pares, assim como espaço de debate das questóes do momento (BROCA, 1991). Coelho Neto era conhecido pela capacidade de atrair e cativar plateias, aproximando-se do sentido atual de "celebridade literária" (TURNER, 2004). Durante uma hora, o escritor ocupou a tribuna e discursou para "numeroso auditório" (Diário de Notícias, 10 out. 1887, p. 2), falou sobre a poesia antiga e atual, para em seguida fazer um panorama da história do romance moderno até chegar ao naturalismo, detendo-se no "grande Emilio Zola". Depois ocupou-se de Aluísio Azevedo, "analisou-o e o expôs ao público, desde o começo de sua carreira até hoje, dia da aparição de $O$ homem". Para fechar em grande estilo, leu "opulentamente" alguns trechos do novo romance, deixando na plateia "a mais violenta e agradável impressão" (Diário de Notícias, 10 out. 1887, p. 2).

As açôes coordenadas de panfletagem, conferência pública e notas simpáticas na imprensa repetiam as estratégias de divulgação do naturalismo na França. O almoço de comemoração no Hotel Londres, no dia do lançamento de $O$ homem, repetia a jogada publicitária do famoso jantar no restaurante La Trapp, em Paris, no dia 16 de abril de 1877, considerado um evento fundador do naturalismo na França (BAGULEY, 1990). O jantar reuniu Zola, Flaubert, Edmond de Goncourt, Joris-Karl Huysmans, Henry Céard, Guy de Maupassant e, crucialmente, o livreiro Georges Charpentier, o "editor dos naturalistas". Anunciado nos jornais com antecedência, o jantar era um evento de divulgaçáo dos escritores naturalistas e de declaraçáo de apoio a Zola, que naquele momento era acusado de pornográfico devido à publicação de L'Assommoir (1877). O "menu de fantasia" era uma peça de divulgação publicitária das obras dos escritores. Os jornais satirizaram e replicaram o cardápio, fazendo reclame: Sopa "Madame Bovary", truta "Fille Elisa”, galinha recheada "Saint Antoine", alcachofra "Cour Simple", parfait naturalista de sobremesa, acompanhado de vinho de Coupeau e licor "Assommoir" (CATHARINA, 2006, p. 107).

$\mathrm{O}$ almoço de lançamento de $O$ homem cumpria funçóes semelhantes. Servia para demonstrar apoio a Aluísio Azevedo - o "moço trabalhador que tanto se esforça por avivar o amortecido brilho das letras brasileiras", nas palavras de José do Patrocínio no Cidade do Rio (11 out. 1887, p. 1) - e ao mesmo tempo divulgar suas obras, criando notícia e mídia. O evento reuniu jornalistas e escritores, com destaque para Adolfo de Castro e Silva - o editor de $O$ homem -, Coelho Neto, os poetas Luis Murat e Guimarães Passos, o jornalista Alcindo Guanabara, diretor do Novidades, entre outros. Durante o almoço, Aluísio declarou que $O$ homem era o precursor de um outro romance "francamente realista", $O$ cortiço. Como os naturalistas franceses, o escritor criou um "menu de fantasia" com suas obras. Um cartão com o 
menu impresso em francês foi colocado na frente do prato de cada conviva: "Hors d'œuvre: Sardines à Magdá; Entrée: Poisson fin au gratin à Mulato; Veau sautée à Coruja; Filet grillé à Homem; Omelette à Casa de Pensão; Dessert: Pouding au chocolat à Mistério da Tijuca; Salade de fruits à Memórias de um Condenado; Fromage à Casa de Orates; Frutas à Lágrima de mulher" (Gazeta da Tarde, 11 out. 1887 , p. 2).

Todos esses movimentos geraram ansiedade e expectativas em torno do aparecimento de $O$ homem. Houve até um boato de que a polícia iria interditar o livro "por ser obra realista" (Revista Ilustrada, 30 set. 1887, p. 3). Esses rumores, logo desmentidos pelos jornais, confirmam que naquela sociedade era prática comum associar o romance naturalista ao discurso pornográfico. As pessoas que acionavam a polícia nesses casos faziam-no com sincera preocupação. No caso de $O$ homem, não houve envolvimento da polícia, mas a existência do boato - que talvez viesse de pessoas ligadas a Aluísio (ou do próprio) - significava que era crível associar a ficção naturalista ao obsceno e ao fora da lei. Houve ameaças de chamada da polícia por ocasiáo do lançamento de outros romances naturalistas, como $A$ carne e $O$ aborto, e também quando $O$ crime do padre Amaro (1875), de Eça de Queirós, foi adaptado e levado aos palcos em 1890 . Os escritores naturalistas, os livreiros e os donos dos teatros náo se importavam, pois sabiam que não havia melhor reclame para uma obra do que ter a polícia no seu encalço.

O sucesso se confirmou. O Cidade do Rio (11 out. 1887, p. 1) noticiou que nas mesas das confeitarias na rua do Ouvidor só se falava do novo livro de Aluísio Azevedo. Cinco dias depois do lançamento já estava quase esgotada a primeira edição ( $A$ Semana, 15 out. 1887, p. 1), que se referia geralmente ao primeiro milheiro. Os editores testavam o mercado com uma primeira tiragem de mil exemplares, e repetiam os milheiros enquanto o livro estivesse em demanda. Pedro Quaresma fez pelo menos cinco milheiros de $O$ aborto em 1893 - marca de sucesso inquestionável -, mas eram a mesma edição. No caso de $O$ homem, as chamadas três primeiras edições são três lotes de 1.900 exemplares, totalizando 5.700 exemplares vendidos entre outubro e dezembro de 1887 (MÉRIAN, 2013). O livro custava 3 mil-réis, o preço médio de um impresso de 300 páginas e equivalente ao que um trabalhador especializado (como um ferreiro) recebia por um dia de trabalho. Os milhares de leitores de $O$ homem evidentemente não incluíam somente letrados interessados no desenvolvimento da literatura nacional. $\mathrm{O}$ sucesso foi um feito excepcional para livros brasileiros, que precisavam disputar o magro leitorado com livros estrangeiros.

Assim que o livro começou a circular, artigos contra e a favor pipocaram em periódicos do Rio, das províncias e até de Portugal. As referências ao erotismo são constantes nas reaçóes dos leitores. Admitindo que não havia 
lido a obra, o crítico do conservador Jornal do Commercio (12 out. 1887, p. 1) adianta que $O$ homem náo era livro "nem para homens nem para senhoras", por conta da obscenidade e da linguagem chula. O periódico chegou a censurar referências às obras de Aluísio Azevedo em suas páginas. Consciente de que maldizendo a obra por obscenidade estava involuntariamente contribuindo para sua publicidade, o crítico desabafa: "exaramos aqui esta nossa opiniāo, certos que ela renderá mais para a venda de exemplares do que qualquer elogio que fizéssemos". Não tardou para alguns críticos imputarem o êxito de $O$ homem às cenas eróticas dos sonhos de Magdá. J. Rodrigues Guiáo, colaborador paulista de $O$ Paiz, sugere que o verdadeiro motivo do sucesso do novo livro de Aluísio Azevedo era a licenciosidade: "o Zé Povinho pouco se importa com a elevada intuição científica da escola realista, nem quer saber quais os métodos usados por ela, o que ele quer é imoralidade" (04 dez. 1887, p. 2).

A validade dessa chave de leitura é confirmada no romance $O$ aborto, de Figueiredo Pimentel, no qual Aluísio Azevedo e $O$ homem são referenciados como autor e obra pornográficos, dentro e fora da narrativa. $O$ aborto causou grande polêmica por narrar as aventuras de Maricota, uma moça de família remediada de Niterói, que sonha ser igual à prostituta Nana, do romance homônimo de Zola, e invade o quarto do primo Mário para ter relaçôes sexuais, resultando em gravidez indesejada e morte (VIEIRA, 2015). No romance, Mário possui um baú onde esconde uma pequena coleção de livros eróticos. A certa altura, Maricota encontra os livros:

Remexendo os livros do moço, encontrara alguns romances. Eram $O$ homem, de Aluísio Azevedo; O crime do padre Amaro, de Eça de Queirós; Esposa e virgem, de Belot; Nana, de Emilio Zola; as Volúpias, deRabelais; e mais outros. Devorou-os sofregadamente, às ocultas da máe, aprendendo nele coisas completamente ignoradas, e reparando em vários episódios que não compreendia bem, mas onde pressentia grandes imoralidades. Apreciava-os somente pelo lado da bandalheira (PIMENTEL, 2015, p. 72).

A presença expressiva de obras naturalistas no baú - os brasileiros $O$ homem e $A$ carne, que aparecem em outro momento em $O$ aborto; $O$ crime do padre Amaro e Nana (1880) - confirma a percepção de que o naturalismo era confundido com literatura licenciosa. As personagens Maricota e Mário, bem como Figueiredo Pimentel (que tinha 19 anos quando escreveu $O$ aborto), mostram como os jovens do período se apropriavam dos romances do baú, de forma desinteressada pela ciência ou pelo alegado teor pedagógico das obras. Conhecemos outros depoimentos que confirmam essa percepção e explicam o poder de atração desses livros. O escritor Cláudio de Sousa (1876-1954) teve na leitura secreta de $A$ carne o ponto alto de suas férias escolares em 1888 
(apud BULHÔES, 2002); e Gonzaga Duque (1863-1911) confessou que só adquiriu um exemplar de $O$ primo Basílio quando ouviu dizer, em conversas na escola, que havia nudez e sexo no livro (DUQUE, 1900). Os romances naturalistas eram potenciais livros eróticos, capazes de informar e excitar, para serem lidos em segredo e guardados num recipiente fechado à chave.

Na primeira ediçáo de $O$ aborto, Figueiredo Pimentel informa o leitor sobre o furor que a história de Maricota causou quando apareceu em folhetim, em Niterói, em 1889. Desde o início, a obra e o autor vinham sendo acusados de "pornográficos", pois os primos aparecem tendo relaçóes sexuais mais de uma vez e conversam sobre preservativos e menstruação. Por isso, a edição em livro é acompanhada de um "prefácio indispensável", no qual situa a obra nesse contexto. Na dedicatória à Exma. Sra. D. Margarida Eufrásia Barreto Cavalcanti de Albuquerque, Figueiredo Pimentel adverte:

(...) pouco me importa que ele $[O$ aborto] seja pechado de pornográfico, imoral, bandalho. Para mim, será até uma honra e uma glória: Emílio Zola, Eça de Queirós, Aluísio Azevedo, Pardal Mallet - todos os naturalistas - para este público besta, que lê os Seróes de Convento e vê operetas, são também pornográficos, imorais e bandalhos (PIMENTEL, 2015, p. 21).

Admite que poderiam acusá-lo de escritor "pornográfico, imoral e bandalho". Assinala que assim foram julgados outros grandes escritores naturalistas, como Zola, Eça de Queirós e Aluísio Azevedo, reivindicando a glória de pertencer a esse panteão. Para Figueiredo Pimentel, somente sujeitos com hábitos questionáveis de leitura, habituados a ler Os seróes do convento, julgariam seu livro imoral. Feita para negar o parentesco entre o naturalismo e a pornografia, a comparação só fazia confirmar, aos olhos do público, as semelhanças entre os livros e suas práticas textuais. Como a advertência de $O$ homem, o prefácio de $O$ aborto reconhecia enviezadamente que o naturalismo era pornográfico para muitos leitores. Negar essa relação era uma forma de chamar a atençáo para o conteúdo erótico, funcionando como reclame da obra.

A estratégia de marketing de sentido ambíguo funcionou, servindo para manter viva a polêmica sobre a história de Magdá. Menos de dez meses depois da primeira edição, a proeminente livraria-editora Garnier comprou os direitos de toda a obra de Aluísio Azevedo. Era um símbolo importante de consagração literária. Situada na rua do Ouvidor, a Garnier era uma das livrarias mais antigas da cidade e oferecia ao público o melhor do cânone literário internacional (HALLEWELL, 1985). Quando passou a editar literatura brasileira, continuou com a mesma estratégia, publicando apenas obras de escritores que já haviam alcançado consagração literária (EL FAR, 2004). Assim a livraria Garnier conquistou um lugar especial no mercado editorial carioca até o início do século XX. Era a editora de José de Alencar e 
Machado de Assis. Além de uma quarta nova edição de $O$ homem, a Garnier fez novas ediçôes de $O$ mulato, $O$ Coruja e Casa de Pensáo, assim como colocou O cortiço na linha de produção. Quando foi publicado, em 1890, O cortiço tinha todos os ingredientes de sucesso: o selo da Garnier, a reputação de autor erótico de Aluísio Azevedo, o investimento na "cor local" - ao contrário de $O$ homem, que foi criticado por isso - e o preço mais em conta: 2 mil-réis. O livro causou grande impacto e foi outro best-seller de Aluísio Azevedo (MÉRIAN, 2013).

O homem: Revista dos acontecimentos do ano de 1887

O êxito de $O$ homem animou Arthur Azevedo e Moreira Sampaio a escrever a peça homônima $O$ homem: Revista dos acontecimentos do ano de 1887, aproveitando partes da história de Magdá como fio condutor do espetáculo. As Revistas de ano eram um gênero de teatro popular, e tiveram início na década de 1880. Nos primeiros dias de janeiro, os espetáculos "passavam em revista" os principais acontecimentos políticos, artísticos, econômicos e literários do ano que findava, mesclando o registro factual com a ficcionalização humorística do cotidiano (SUSSEKIND, 1986). Não raro os escritores incluíam o aparecimento de seus livros como eventos marcantes. Tudo era personificado em cena e ganhava "tratamento cômico, algumas vezes de alcance crítico ou satírico" (FARIA, 2001, p. 161). Artur Azevedo foi o revistógrafo brasileiro mais conhecido e produtivo. Ele escreveu 19 peças num período de duas décadas. Destas, apenas a revista $O$ homem foi inspirada em obra naturalista.

Assim como a opereta, a revista de ano era considerada um gênero menor, distante da arte literária autêntica. Era entretenimento acrescido da corporalidade intrínseca ao palco, com números de música e dança. $\mathrm{O}$ fio da história era menos importante do que a sucessão de quadros alegres, apresentaçôes musicais e até exibições de conquistas recentes da ciência. A revista $O$ homem, por exemplo, incluía uma demonstração dos "efeitos deslumbrantes" da luz elétrica, assim como tradicionais números musicais de jongo e lundu. A fama de livro erótico de $O$ homem era um bom reclame. A coluna teatral de $A$ Semana noticiou que, na estreia a 3 de janeiro de 1888 , "a curiosidade despertada pelo apimentado título desta revista teatral atraiu tantos espectadores ao Éden-Teatro, que bem se pode dizer que houve mais do que enchente, houve transbordamento, senão verdadeira apoplexia do público" (7 jan. 1888, p. 2). O entusiasmo do periódico de Valentim Magalhães podia ser exagerado, mas mostra como os escritores estavam cientes do conteúdo erótico da obra e como se serviam dele para atrair público. A referência ao "Éden-Teatro" sugeria que toda a audiência seria transportada ao paraíso dos sonhos quentes de Magdá. 
Dois meses após o lançamento do romance, já se podia ler nos jornais que os ensaios da peça haviam começado, com estreia programada no Teatro Lucinda para o início de 1888. Aluísio Azevedo ficou responsável pela criação dos vestuários e adereços. Em 18 de outubro, a Gazeta de Notícias e o Diário de Notícias anunciam a aprovação da Revista de ano de 1887 - O homem pelo Conservatório Dramático, com o parecer favorável de Machado de Assis. Porém, quando a peça subiu aos palcos, os espectadores previsivelmente ficaram de "bico doce a suspirar por mais" (A Semana, 07 jan. 1888, p. 2). Como ocorria na França na transposição dos romances naturalistas para o palco, as partes picantes foram cortadas (FARIA, 2001). Foram suprimidos os sonhos voluptuosos de Magdá. Mas o fato de que os protagonistas "percorrem toda a cidade do Rio de Janeiro à procura de um homem que cure os histerismos de Magdá" (Gazeta de Notícias, 5 jan. 1888, p. 2) mantinha o sexo como principal fio condutor do espetáculo.

Os autores davam ao assunto o tratamento adequado para uma comédia (FARIA, 2017). Com tiradas burlescas capazes de arrancar gargalhadas do público, a Revista traçava um final feliz para a histérica Magdalena, ingrediente exigido pela convençáo do gênero cômico. Na peça, ao contrário do romance, Magdá e Fernando não são irmãos. Ele é filho do Dr. Lobão e não morre. Fernando reencontra a protagonista ao retornar de Portugal. A máe revela ter percorrido em váo toda Lisboa à procura de uma mulher para o filho, por recomendação médica. Polemicamente, no romance e na peça, o sexo aparece como necessário para a boa saúde da mulher e do homem. Já o Dr. Lobão, de médico "ridículo" e "caricato" no romance (SEREZA, 2012, p. 187), transforma-se no palco em "charlatão", mostrando como o discurso médico podia ser criticado até mesmo na obra naturalista. A revista ficou em cartaz até início de março de 1888, percorrendo vários teatros da corte e de São Paulo. O espetáculo contribuiu para que novas críticas favoráveis e desfavoráveis a $O$ homem fossem publicadas nos jornais, mantendo a obra em pauta ao longo de 1888 .

\section{Considerações finais}

De certo é impossível recriar o "mundo mental" em que ocorria a leitura dos romances licenciosos no passado, com seus pressupostos, valores e códigos característicos (DARNTON, 1996, p. 35). Cada leitor recria o texto de uma nova maneira, de acordo com seus âmbitos de competência textual e suas especificidades, incluindo a capacidade de comparar o texto com outros que leu, não previstos ou sequer conhecidos pelo autor do texto original (CHARTIER, 1988). Sem sermos capazes de responder a todas essas perguntas, podemos, entretanto, dizer que a apropriação erótica de romances naturalistas foi prática de leitura disseminada no fim do século 
e razão fundamental de sua popularidade e rentabilidade. O trabalho do pesquisador é compreender como era possível que um romance como $O$ homem se transformasse em best-seller erótico, e não acusar os leitores do passado de um mal-entendido. Quando comparamos o romance de Aluísio Azevedo com outros livros licenciosos do período, é possível imaginar como e por que livros como $O$ homem, $A$ carne e $O$ aborto eram capazes de "irritar os nervos" e "ativar a vontade" do leitor, como prometiam as livrarias da época.

Os escritores naturalistas evidentemente rejeitavam a insinuação de que escreviam literatura licenciosa e se explicavam com a atribuição de uma intenção pedagógica ao enredo picante. $\mathrm{O}$ objetivo, justificavam, não era incentivar a imoralidade, mas denunciá-la por meio da observação e do estudo. Como a historiografia tende a naturalizar a autoimagem dos escritores, ela destaca a intenção pedagógica como marca do naturalismo, sem considerar a circulação e vendas dos livros, ou as formas como eram apropriados e lidos por leitores não especialistas e livreiros. São inúmeras as evidências de que $O$ homem e outros romances naturalistas eram textos propagadores de "conhecimento carnal" (PORTER, 1995) naquela sociedade, especialmente valorizados pelos jovens e pelo leitor comum. Nessa leitura desinteressada pela ciência (e até pelo enredo e pela tragédia), a patologização do sexo perde gravidade. Isso náo significa negar a presença do estudo teórico sobre a patologia do histerismo no romance, mas constatar que a intenção pedagógica (ou médica) nem sempre se realizava na leitura.

O homem não foi apenas um romance de Aluísio Azevedo, mas um bemsucedido projeto artístico-empresarial em que o escritor maranhense ocupou lugar de destaque. $\mathrm{O}$ intenso trabalho empreendido visava gerar renda, mas também ocupar e fundar um campo artístico nacional, dar respeitabilidade e visibilidade à profissão de escritor, culminando na criação da Academia Brasileira de Letras em 1897. Os produtos desse projeto (livro e peça teatral) agradaram às massas e aos pares porque seus criadores conheciam o limite permitido de licenciosidade sem perder a respeitabilidade burguesa, que era essencial para manter a reputação de artistas "sérios". Mas o apoio dos pares não impedia que outros letrados chamassem Aluísio Azevedo de "escritor perigoso para a sociedade" (Gazeta da tarde, 04 set. 1888, p. 3). O sucesso do romance possibilitou ao romancista entrar para o prestigiado rol dos escritores editados pela livraria Garnier. Ironicamente, foram as concessóes ao erótico e ao popular em $O$ homem que permitiram a Aluísio Azevedo galgar mais um degrau em direção à glória literária. 


\section{Referências}

AZEVEDO, Aluísio. O homem. 3a. ed. Rio de Janeiro: Typ. de Adolpho de Castro Silva, 1887. Disponível em: <https://digital.bbm.usp.br/handle/bbm/4893>

AZEVEDO, Aluísio. O homem. São Paulo: Martins, 1989.

BAGULEY, David. Naturalist fiction. The entropicvision. Cambridge: Cambridge UP, 1990 .

BOSI, Alfredo. História concisa da literatura brasileira. São Paulo: Cultrix, 1972.

BROCA, Brito. Naturalistas, parnasianos e decadistas. Vida literária do realismo ao pré-modernismo. Campinas: Editora Unicamp, 1991.

BULHÓES, Marcelo. Leituras de um livro obsceno. Em: Ribeiro, Júlio. A carne. São Paulo: Ateliê Editorial, 2002, p. 9- 59.

CANDIDO, Antônio. Formação da literatura brasileira: momentos decisivos, 17501880. Rio de Janeiro: Ouro sobre Azul, 2013.

CATHARINA, Pedro Paulo. Revendo o naturalismo. In: Mello, Celina Maria Moreira de \& Catharina, Pedro Paulo (org.). Cenas da literatura moderna. Rio de Janeiro: 7Letras, 2010, p. 71-90.

CHARTIER, Roger. A História Cultural: entre práticas e representaçóes. Rio de Janeiro: Bertrand, 1988.

DARNTON, Robert. Sexo dá o que pensar. Em: Novaes, Adauto (org.). Libertinos e libertários. São Paulo: Cia das Letras, 1996: 21-42.

DUQUE, Luiz Gonzaga. O Primo Basílio. Notas sobre um fato. Revista Contemporânea, n. 19 , out., $7-12,1900$.

EL FAR, Alessandra. Páginas de sensação.Literatura popular e pornográfica no Rio de Janeiro (1870-1924). São Paulo: Cia. das Letras, 2004.

FARIA, João Roberto. Ideias teatrais - O século XIX no Brasil. São Paulo: Perspectiva: FAPESP, 2001.

Arthur Azevedo e a revista de anno: $O$ homem. O eixo e a roda, Belo Horizonte, v. 26, n.2, , p. 229-251, 2017.

GALLIS, Alfredo. Mártires da virgindade. Romance patológico. São Paulo: Ediçóes Júpiter, s.d.

GARCIA-CAMELLO, Cleyciara. A filha do conselheiro: cientificismo, licenciosidade e promoção publicitária em $\mathrm{O}$ homem, de Aluisio Azevedo. Dissertação (Mestrado em Literatura Brasileira). Rio de Janeiro: Universidade do Estado do Rio de Janeiro, 2018. 
HALLEWELL, Laurence. O livro no Brasil (sua história). São Paulo, EDUSP, 1985.

HEMEROTECA Digital Brasileira. <http://memoria.bn.br/hdb/periodico.aspx>

LAMONICA, Lucas de Castro. Filomena Borges: romance, imprensa e politica. Dissertação (Mestrado em História e Historiografia Literária). Campinas: UNICAMP, 2015.

MAINGUENEAU, Dominique. $O$ discurso pornográfico. São Paulo: Parábola Editorial, 2010.

MENDES, Leonardo. Livros para Homens: sucessos pornográficos no Brasil no final do século XIX. Cadernos do IL, Porto Alegre, n. 53, p. 173-191, 2016.

MÉRIAN, Jean-Yves. Aluísio Azevedo: vida e obra (1857-1913). Rio de Janeiro: Garamond, 2013.

MOULTON, Ian Frederick. Before Pornography: Erotic writing in early modern England. Oxford: Oxford University Press, 2000.

PEAKMAN, Julie. Mighty lewd books: the development of pornography in eighteenthcentury England. London: Palgrave Macmillan, 2003.

PEREIRA, Lucia Miguel. Prosa de fiçã̃o (de 1870 a 1920). História da literatura brasileira. São Paulo: EDUSP, 1988.

PIMENTEL, Alberto Figueiredo. O aborto. Rio de Janeiro: 7Letras, 2015.

PORTER, Roy. Forbidden Pleasures: Enlightenment literature of sexual advice. In: Bennett, Paula \& Rosario, Vernon (ed.). Solitary Pleasures: The Historical, Literary, and Artistic Discourses of Autoeroticism. New York; Routledge, 1995, p. 75-98.

REAL GABINETE Português de Leitura. <http://www.realgabinete.com.br/>

SEREZA, Haroldo Ceravolo. O Brasil na Internacional Socialista: Adequação da estética, do método e da temática naturalistas no romance brasileiro do século XIX. Tese (Doutorado em Literatura Brasileira). São Paulo: Universidade de São Paulo, 2012.

SÜSSEKIND, Flora. As revistas de ano e a invenção do Rio de Janeiro. Rio de janeiro: Nova Fronteira, 1986.

THAUVETTE, Chantelle. Defining early pornography: the case of "Venus and Adonis". Journal for EarlyModern Cultural Studies, v. 12, n. 1, p. 26-48, 2012.

TURNER, Graeme. Understanding Celebrity. Los Angeles: Sage, 2004.

VIEIRA, Renata Ferreira. Uma penca de canalhas: Figueiredo Pimentel e o naturalismo no Brasil. 2015. Dissertação (Mestrado em Teoria da Literatura), Universidade do Estado do Rio de Janeiro, Rio de Janeiro, 2015. 
Leonardo Mendes. Professor Associado de Estudos Literários, Departamento de Letras, Faculdade de Formação de Professores da Universidade do Estado do Rio de Janeiro. Professor permanente do Programa de Pós-graduação em Letras da Universidade Estadual do Rio de Janeiro.

E-mail: leonardomendes@utexas.edu

Cleyciara Garcia Camello. Graduada em Letras pela Universidade Federal Fluminene e Mestre em Literatura Brasileira pela Universidade do Estado do Rio de Janeiro.

E-mail: cleyciaracamello@gmail.com 